\title{
Analysis of Sweet Cherry (Prunus avium L.) Cultivars Using SSR and AFLP Markers
}

\author{
Darush Struss, Riaz Ahmad, and Stephen M. Southwick1 \\ Department of Pomology, University of California Davis, CA 95616 \\ Manuela Boritzki \\ Institute of Plant Genetics and Crop Plant Research (IPK), Corrensstr. 3, 06466 Gatersleben, Germany
}

AdDitional INDEX words. Prunus, microsatellites, molecular markers, cultivar identification

\begin{abstract}
Simple sequence repeats (SSRs) and amplified fragment-length polymorphisms (AFLPs) were used to evaluate sweet cherry (Prunus avium L.) cultivars using quality DNA extracted from fruit flesh and leaves. SSR markers were developed from a phage library using genomic DNA of the sweet cherry cultivar Valerij Tschkalov. Microsatellite containing clones were sequenced and 15 specific PCR primers were selected for identification of cultivars in sweet cherry and for cross-species amplification in Prunus. In total, 48 alleles were detected by 15 SSR primer pairs, with an average of 3.2 putative alleles per primer combination. The number of putative alleles ranged from one to five in the tested cherry cultivars. Forty polymorphic fragments were scored in the tested cherry cultivars by 15 SSRs. All sweet cherry cultivars were identified by SSRs from their unique fingerprints. We also demonstrated that the technique of using DNA from fruit flesh for analysis can be used to maintain product purity in the market place by comparing DNA fingerprints from 12 samples of 'Bing' fruit collected from different grocery stores in the United States to that of a standard 'Bing' cultivar. Results indicated that, with one exception, all 'Bing' samples were similar to the standard. Amplification of more than $80 \%$ of the sweet cherry primer pairs in plum $(P$. salicina $)$, apricot $(P$. armeniaca $)$ and peach $(P$. persica $L$. $)$ showed a congeneric relationship within Prunus species. A total of $63(21 \%)$ polymorphic fragments were recorded in 15 sweet cherry cultivars using four EcoRI-MseI AFLP primer combinations. AFLP markers generated unique fingerprints for all sweet cherry cultivars. SSRs and AFLP polymorphic fragments were used to calculate a similarity matrix and to perform UPGMA cluster analysis. Most of the cultivars were grouped according to their pedigree. The SSR and AFLP molecular markers can be used for the grouping and identification of sweet cherry cultivars as a complement to pomological studies. The new SSRs developed here could be used in cherry as well as in other Prunus species for linkage mapping, evolutionary and taxonomic study.
\end{abstract}

The capability to distinguish among cherry (Prunus avium) cultivars in breeding and cultivation is extremely important for scientific as well as for economic reasons. There is a demand for a rapid and reliable method of cultivar identification for Plant Breeder's Rights (PBR) registration and protection. Classical methods of identification and characterization of cultivars in fruits have relied mostly upon a large set of phenotypic data that is often difficult to assess, may vary with environment and production practices, and can be time consuming to collect when surveying large populations that may be growing in different locations. Molecular markers based on DNA are stable, detectable in all tissues and independent of environmental or seasonal conditions. They can be used for cultivar identification, diversity analysis, assessment of parentage, patent issues and quality control of rootstock-seed lots. The ability to distinguish cherry cultivars would be greatly enhanced by the use of molecular markers.

Molecular marker development and use within Prunus species has been most active in peach ( $P$. persica) due to its relatively short juvenile period and commercial importance (Dirlewanger and Bodo, 1994; Sosinski et al., 1998). A variety of molecular techniques have been developed for measuring genetic variability. Of the possible alternatives, isozymes have been shown to be insufficiently variable in cherry due to low polymorphism of the species ( Tobutt and Boskovic, 1996). Randomly amplified polymorphic DNA (RAPD) markers have also been assayed in fruit

Received for publication 30 Dec 2002. Accepted for publication 24 June 2003. We thank the California Sweet Cherry Advisory Board for partial funding of this work. We appreciate the critical reviews of this manuscript by Dan Potter, David Hunter and Kitren Glozer.

${ }^{1}$ To whom reprint requests should be addressed; e-mail smsouthwick@ucdavis.edu. trees (Warburton and Bliss, 1996) but poor reproducibility and low multiplexing output limit their use. Two hundred RAPD primers of which only 25 were informative could not distinguish 18 sweet cherry cultivars (Gerlach and Stosser, 1998). Chloroplast DNA, because of its conserved nature, is commonly not recommended as a good molecular marker to distinguish cultivars (Mohanty et al., 2001 ). One of the most reliable molecular marker systems is microsatellites or simple sequence repeats (SSRs) which are abundant and well distributed throughout the nuclear genomes of eukaryotes. These are mostly present in noncoding DNA, which can accumulate mutations more rapidly than the coding DNA. Simple sequence length polymorphism (SSLP) caused by variation in the number of repeat units, can be easily detected by PCR using pairs of primers designed from unique sequences bordering the SSR motifs. SSRs, are generally considered the marker of choice for genetic fingerprinting purposes in fruit trees, due to their high levels of polymorphism, high degree of reliability and reproducibility, and codominant mode of inheritance. In plants, these markers have been used widely for cultivar identification and genetic mapping (Cipriani et al., 1999; Guilford et al., 1997) and are a powerful genetic resource for phylogenetic studies (Provan et al., 1996). Microsatellite loci developed from genomic DNA libraries tend to map randomly throughout the genome and are suitable for comparative genetic studies. The genetic profiles produced by multiplexing specific combinations of microsatellite markers can be used in conjunction with pedigree and performance data to document ownership and protect intellectual property rights (McCouch et al., 1997). Microsatellites have been recognized as a good source of genetic markers in cherry (Cantini et al., 2001; Downey and Iezzoni, 2000), but a major limitation of SSRs is the time and cost 
required to isolate and characterize each locus when a preexisting DNA sequence is not available. In cherry, sufficient sequence data are not available in the database for designing microsatellite primers for analysis. Lengthy cloning and plasmid screening procedures are needed to identify candidate markers.

Another molecular marker, amplified fragment-length polymorphism (AFLP) has been shown to reveal a relatively high degree of polymorphism in sweet cherry (Boritzki et al., 2000; Struss et al., 2001; Tavaud et al., 2001). Zhou et al (2002) found AFLP to be an appropriate method for rapidly developing a fingerprint profile. The high multiplex ratio of AFLP analysis makes it the most efficient method for generating large numbers of anonymous DNA markers for use in genetic linkage and diversity studies. The use of high quality total genomic DNA with complete digestion by restriction enzymes is very important for reproducibilty of the AFLP profile. Consistent differences were observed between AFLP profiles generated from peach leaf and fruit DNA (Aranzana et al., 2001). The present project was designed 1) to establish the presence, abundance and characteristics of the two classes of dinucleotide repeats, $(\mathrm{GA} / \mathrm{CT}) \mathrm{n}$ and $(\mathrm{GT} / \mathrm{CA}) \mathrm{n}$ in the cherry genome, 2) to develop SSR and AFLP fingerprints for identification and characterization of sweet cherry cultivars using DNA extracted from fruit flesh and leaf tissues, and 3) to demonstrate the transferability of SSR markers developed in sweet cherry (P. avium) for molecular analysis in plum ( $P$. salicina Lindl.), apricot ( $P$. armeniaca) and peach $(P$. persica).

\section{Material and Methods}

Plant material. Leaf and fruit samples were collected from 15 sweet cherry cultivars - 'Bing', 'Chinook', 'Van', 'Vista' 'Larian', 'Sam', 'Jubilee', 'Tulare', 'Index', 'King', 'Chelan', 'Early Coral', 'Early Burlat', 'Brooks', and 'Skeena' (only leaf sample was available) - from mature trees located in Winters, Calif. In addition, 12 fruit samples of 'Bing' sweet cherry were collected from different grocery stores in the United States. For cross species amplification of SSRs, leaf tissue obtained from 'Santa Rosa' plum, 'Patterson' apricot and 'Elegant Lady' peach were used for DNA extraction.

DNA EXTRACTION FROM FRUIT AND LEAVES. DNA was extracted from young expanding leaves and green to ripe fruit flesh corresponding to Centre Technique Interprofessionel des FruitetLegumes (CTIFL) code color chips 1 to 4 . Whole fruit and leaves were first cleaned with dd $\mathrm{H}_{2} \mathrm{O}$. About 200 to $250 \mathrm{mg}$ of fruit (including both skin and flesh while excluding developing seeds in immature fruit) or leaf sample were collected in a 1.5-mL Eppendorf tube, put in liquid nitrogen and stored at or below $-70{ }^{\circ} \mathrm{C}$ until used. Care was taken to avoid thawing before grinding. The samples were ground to powder using mortar and pestle in the presence of liquid nitrogen. To this was added $500 \mu \mathrm{L}$ preheated extraction buffer $(2 \% \mathrm{CTAB}$, $100 \mathrm{~mm}$ Tris-HCl, pH 8.0, $1.4 \mathrm{~m} \mathrm{NaCl}, 20 \mathrm{~mm}$ EDTA, 1\% PVP40 and $10 \mathrm{~mm}$ DTT) and $10 \mu \mathrm{L}$ proteinase $\mathrm{K}$ to each sample. The samples were incubated for $30 \mathrm{~min}$ at $65^{\circ} \mathrm{C}$, extracted with 500 $\mu \mathrm{L} 24$ chloroform : 1 isoamyl alcohol, and centrifuged at $9750 g_{\mathrm{n}}$ for $5 \mathrm{~min}$. The resulting supernatant was transferred into a new $1.5 \mathrm{~mL}$ Eppendorf tube to which $500 \mu \mathrm{L}$ phenol was added, and incubated for $5 \mathrm{~min}$ followed by centrifugation at $9750 g_{\mathrm{n}}$ for 5 min. The upper phase was removed, the milky phase collected and transferred into a new tube, and $500 \mu \mathrm{L}$ chloroform was added prior to centrifugation for $5 \mathrm{~min}$ at $9750 \mathrm{~g}_{\mathrm{n}}$. The aqueous phase was mixed with 0.6 volume of ice-cold 2-isopropanol and centrifuged for 10 min at $9750 g_{\mathrm{n}}$. The supernatant was discarded and the pellet was washed with $1 \mathrm{mLice}$-cold $70 \%$ ethanol. The dried DNA pellet was re-suspended in $50 \mu \mathrm{L}$ distilled water and stored at $4{ }^{\circ} \mathrm{C}$.

DNA extracted from fruit or leaf tissue was purified by adding $1 / 10$ volume $3 \mathrm{~m}$ sodium acetate and 2 volumes $100 \%$ ethanol with subsequent storage at $-20{ }^{\circ} \mathrm{C}$ for $1 \mathrm{~h}$. The samples were centrifuged at $9750 g_{\mathrm{n}}$ for $15 \mathrm{~min}$. Pellets were washed twice with $70 \%$ ethanol, air dried and resolved in $50 \mu \mathrm{L} \mathrm{TE}$ buffer $(10$ mм Tris, 1 mм EDTA, pH 7.5). DNA quality and quantity were measured with ethidium bromide-stained $1 \%$ agarose gel and the $\mathrm{A}_{260}: \mathrm{A}_{280}$ ratio was determined using UV-2401 spectrophotometer (Shimadzu Scientific Instrument, Inc., Pleasanton, Calif.). Quality of the DNA was also verified by complete digestion with EcoR1 and $M S e 1$ restriction enzymes for AFLP and PCR amplification for marker analysis.

SCREENING AND IDENTIFICATION OF MiCrosatellite LOCI. SSR markers were developed following the procedure of Struss and Plieske (1998). For constructing a phage library, $50 \mathrm{ng}$ genomic DNA of the sweet cherry cultivar Valerij Tschkalov was digested with the methylation sensitive restriction enzyme Pst I. The low molecular weight fraction was isolated from an agarose gel, digested with $M b o 1$ and cloned into the BamH1 site of the phage vector Zap express (Stratagene, La Jolla, Calif.). The library was screened for the presence of repeats by hybridization with $(\mathrm{GA})_{10}$ and $(\mathrm{GT})_{10}$ probes, labeled by random priming with ${ }^{32} \mathrm{PCTP}($ Feinberg and Vogelstein, 1983). Positive plaques were isolated and used to transfect Escherichia coli strain XL1 blue. The colonies were again hybridized with $(\mathrm{GA})_{10}$ and $(\mathrm{GT})_{10}$ probes and positive clones were sequenced using an auto sequencer (ABI 373; Global Medical Instrumentation, Inc., Albestville, Minn.). Sequencing was performed by using M13 (-21) as a forward primer. In some cases when the insert was long, resequencing was done by using M13 reverse primer.

MARKER ANALYSIS. For each unique SSRs that contained sufficient reliable flanking sequence, 15 PCR primer pairs were selected using the primer selection computer program Primer 3 (Cambridge, Mass.). The forward primers were labeled with IRD800 and IRD-700 at the 5' end to be detected simultaneously on an automated DNA sequencer (LI-COR, Lincoln, Nebr.). PCR was carried out in a DNA engine tetrad thermal cycler (MJ Research, Inc., Waltham, Mass.) with a total volume of $12 \mu \mathrm{L}$ under the following conditions: 20 to $25 \mathrm{ng}$ of template DNA, $250 \mathrm{~nm}$ of each primer, $200 \mu \mathrm{M}$ of dNTPs, $1 \mathrm{U}$ of Taq Polymerase, 1.5 to $2 \mathrm{~mm}$ of $\mathrm{MgCl}_{2}$. The reaction, depending on the primer pair, was run for 35 to 45 cycles (denaturing at $94^{\circ} \mathrm{C}$ for $1 \mathrm{~min}$, annealing at 55 or 60 ${ }^{\circ} \mathrm{C}$ for $1 \mathrm{~min}$, with a $2 \mathrm{~min}$ extension at $72^{\circ} \mathrm{C}$ ), followed by a single extension at $72^{\circ} \mathrm{C}$ for $60 \mathrm{~min}$. One microliter of reaction products were mixed with $6 \mu \mathrm{L}$ of formamide dye, denatured at $94^{\circ} \mathrm{C}$ for $3 \mathrm{~min}$, and rapidly cooled on ice for $3 \mathrm{~min}$. Amplified fragments from both fruit and leaf DNA were separated by electrophoresis on 0.25 -mm-thick $5.5 \%$ polyacylamide gels and visualized using a DNA sequencer (Gene Readir 4200; LI-COR). Gene Image IR analysis software (Scanalytic, Fairfax, Va.) was used for measuring SSR allele size. Manual editing of the allele size was performed for more accuracy.

To complement the SSR markers, AFLPs were tested on the same cultivars. Restriction, ligation, and preamplification reactions were performed following the original AFLP protocol of Vos et al. (1995) with some modifications suggested by Myburg et al. (2001) for using EcoRI labeled primer with infrared dye IRDye800 or IRDye-700 (LI-COR) at the 5' end to be detected on the DNA sequencer (Long Readir 4200; LI-COR). Preamplification reactions were performed with standard EcoRI $(\mathrm{E}+\mathrm{A})$ and $M s e \mathrm{I}$ 
$(\mathrm{M}+\mathrm{C})$ adapter primers (Vos et al., 1995). Standard EcoRI and MseI adapter primers with three selective nucleotides (i.e., E + ATA and $\mathrm{M}+\mathrm{AGT}, \mathrm{M}+\mathrm{ACT}, \mathrm{M}+\mathrm{ATC}, \mathrm{M}+\mathrm{CAA})$ were used for final selective amplification. Only bright, clearly distingushable bands were used in the genetic analysis. Apparent polymorphisms appearing below 50 base pairs (bp) and above 600 to $700 \mathrm{bp}$ of the banding patterns were rejected due to the inconsistancy of amplification and weakness of bands. AFLP fragments generated from fruit flesh and leaf DNA were run side by side on $5.5 \%$ polyacrylamide gels $(0.25$-mm spacer thickness $)$ and detected by a two-dye (model 4200; LI-COR) automated DNA sequencer. At least one lane per gel loading was loaded with 50 to $700 \mathrm{bp}$ sizing standard labeled with the corresponding IRDye (LI-COR). To test the reproducibility of the AFLP banding patterns, two independent PCR amplifications were performed on the same samples, run side by side and detected on a LI-COR automatic sequencer.

SSRs and AFLP fragments were scored visually as the presence of fragment (1) or absence of fragment (0). The PAUP 4.0b10 software package (Swofford, 1999) was used to generate a mean character difference matrix and then to produce a dendrogram using the unweighted pair group method based on arithmetic averages (UPGMA).

\section{Results and Discussion}

DNA EXTRACTION. The extracted DNA from fruit flesh and leaf samples was of sufficient quality for marker analysis. DNA yield was from 8 to $12 \mu \mathrm{g} \cdot \mathrm{g}^{-1}$ of the starting material. DNA appeared to be of high molecular weight with little shearing and easy mobility. A discrete band on agarose gel was observed for DNA extracted from green (concentration 35 to $46 \mathrm{ng} \cdot \mu \mathrm{L}^{-1}$ ) and ripe (concentration 40 to $\left.55 \mathrm{ng} \cdot \mu \mathrm{L}^{-1}\right)$ fruit. Over-ripe fruit samples showed DNA concentration of 15 to $20 \mathrm{ng} \cdot \mu \mathrm{L}^{-1}$, but the band on agarose gel was not discrete. The $A_{260}: A_{280}$ ratio for green and ripe samples was $\approx 1.8$, but for samples isolated from over-ripe fruits, this ratio was between 1.51 and 1.64 . The $\mathrm{A}_{260}: \mathrm{A}_{280}$ ratio was in the range of 1.79 to 1.85 for DNA samples from leaf tissues. DNA extracts of some samples which showed browning were greatly reduced with the purification step using 3 m sodium acetate.

LIBRARY SCREENING AND SEQUENCE CHARACTERIZATION. The frequencies of dinucleotide repeats in the sweet cherry genome was estimated among 80,000 plaques from a lambda genomic library by hybridization under stringent conditions with the dinucleotide repeats $(\mathrm{GA})_{10}$ and $(\mathrm{GT})_{10}$. In total, 478 clones showed positive signals after hybridization with $(\mathrm{GA})_{10}$ and $(\mathrm{GT})_{10}$. Eighty-two positive clones were sequenced. Forty-two clones $(51.2 \%)$ contained dinucleotide SSRs, of which 31 clones (73\%) had dinucleotide GA/ CT repeats, while $26 \%$ displayed GT/CA repeats. Eighty percent of the clones having dinucleotide (GA)n and (GT)n repeats were 10 to $20 \mathrm{bp}$ long. Eight clones (19\%) had compound sequences which consisted of classes of di, tri, and tetra-nucleotide repeats alternating with (GA)n and (GT)n repeats. Imperfect repeat sequences were relatively rare (around 5\%). Similarly four clones $(9.5 \%)$ were found to be redundant. In the 42 clones having a dinucleotide mi-

Table 1. Primer sequences, repeat motif, number of putative alleles, and their size in base pair amplified by 15 SSRs in cherry cultivars. Cross species amplification of these SSRs in other Prunus species have also been shown.

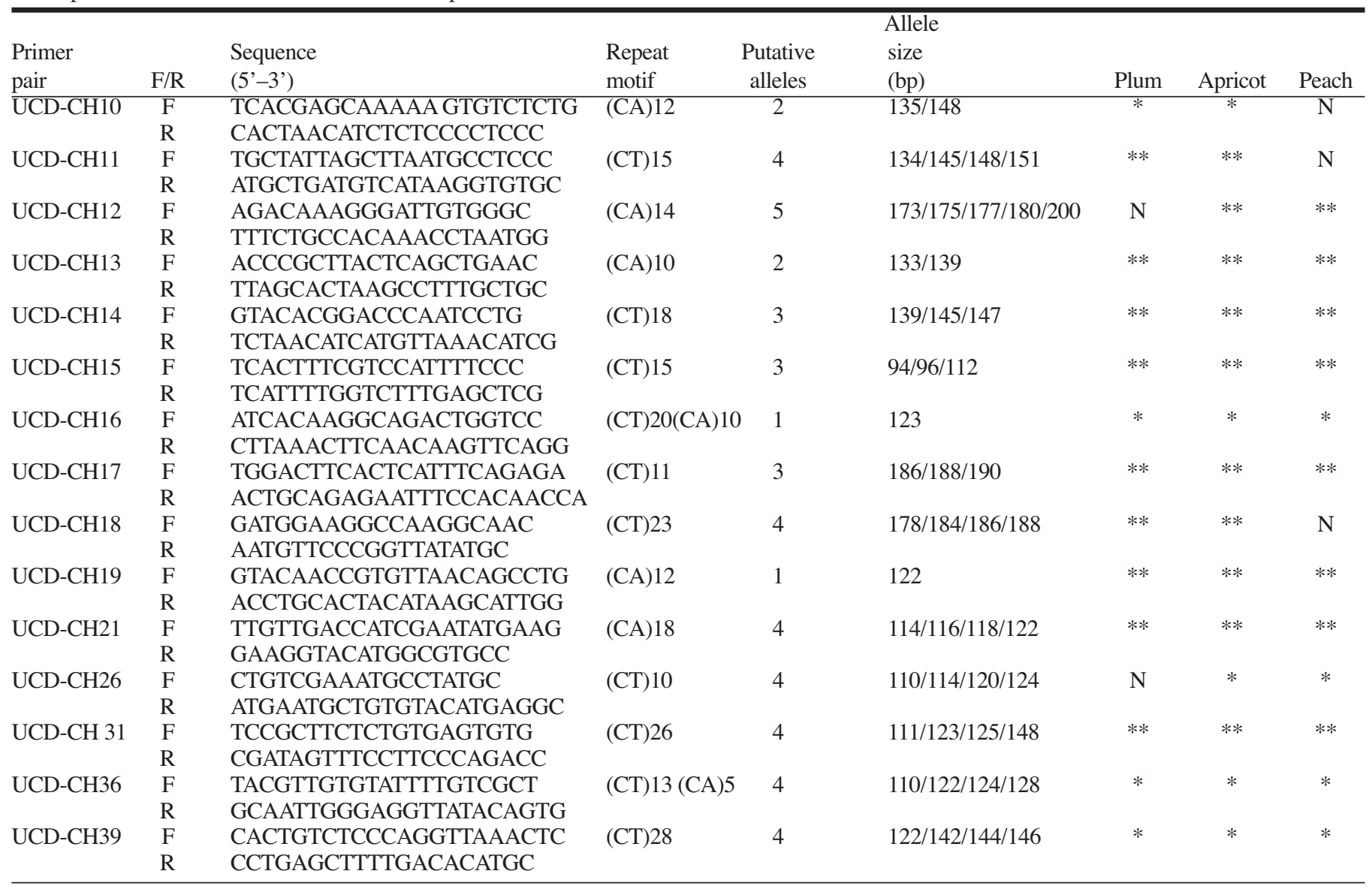

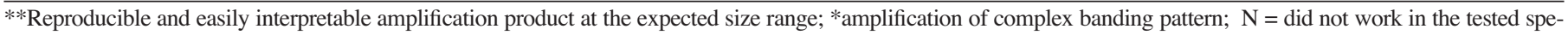
cies. 


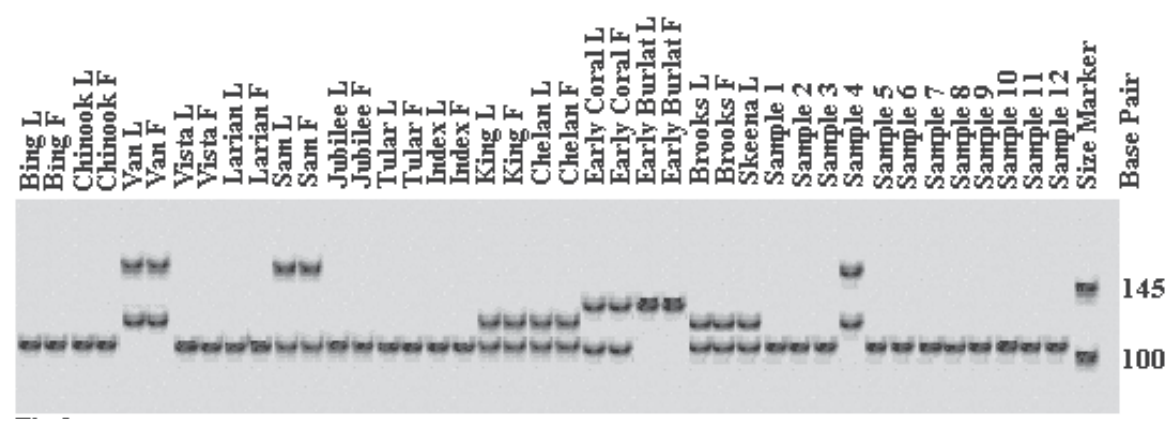

Fig.1. Amplification products using SSR primer pair UCD-CH31 with 15 sweet cherry cultivars. Both leaf and fruit DNA were used as a template in the amplification reaction. Samples 1 to 12 are DNA fingerprints from 'Bing' fruits collected from grocery stores in the United States. Band size is in base pair (bp) using LI-COR size marker.

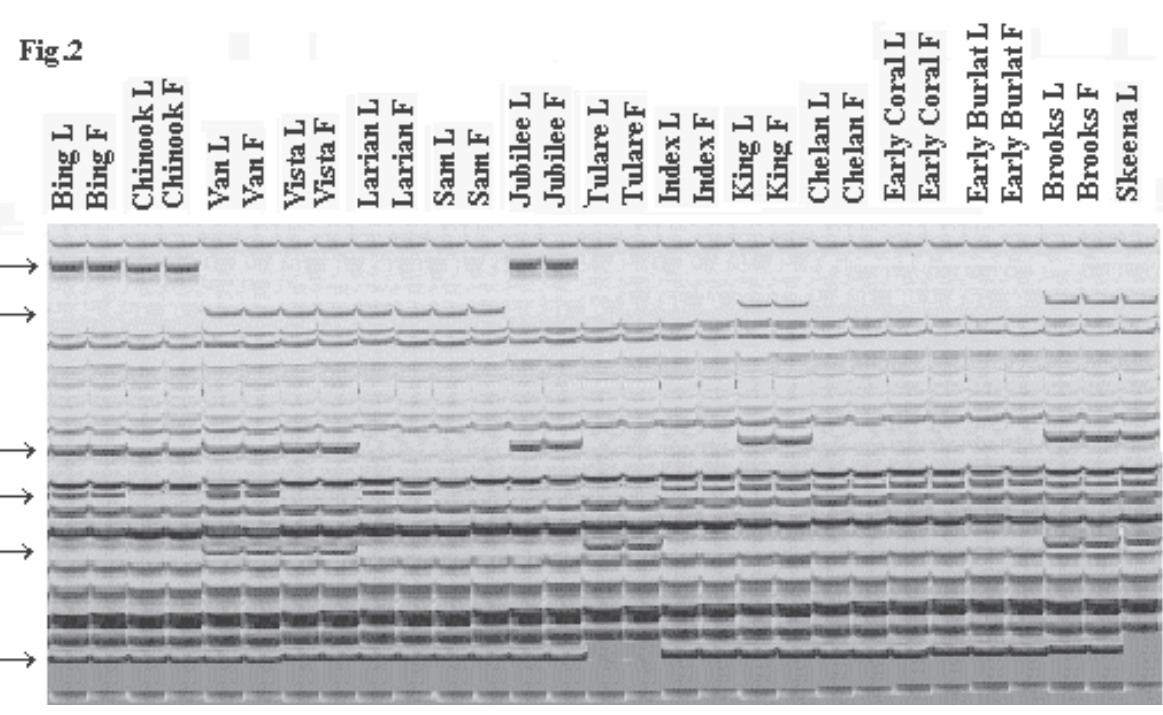

have shown the most frequently occurring dinucleotide repeats to be (AT)n with (CT)n and $(\mathrm{AC}) \mathrm{n}$ as second and third most frequent (Echt and May-Marquardt, 1997; Wang et al., 1994). In cherry, the (GT/CA)n motif have more compound microsatellites. This result is in agreement with that of Raffaele et al. (2000) 45 for the peach (P. persica L. Batsch) genome. Condit and Hubble (1991) observed that 10\% to $20 \%$ of phage inserts that carried a CA repeat also carried a CT repeat, indicating a clustering of repeat regions.

Marker ANALYSIs. The 15 microsatellite-specific primer pairs which resulted in a clear PCR product, were further tested for their efficiency in detecting polymorphisms among 15 cherry cultivars and 12 'Bing' samples collected from the market place. Primer pairs, repeat motif, number of putative alleles and their expected size in base pair amplified by 15 SSRs in sweet cherry cultivars are shown in Table 1. All SSRs were single locus and no complex banding pattern was observed. Thirteen SSRs were polymorphic while the amplification patterns obtained with UCD-CH16 and UCD-CH19 did not show any polymorphism. A total of 48 putative alleles were detected with an average of 3.2 alleles per primer combination. The number of alleles ranged from one to five in this small set of cherry cultivars. One or two alleles per cultivar indicated the diploid nature of the cherry genome. No correlation between the number of repeats of a microsatellite and the number of alleles detected within the tested cherry cultivars was observed. SSR markers identified all cultivars from their unique DNA fingerprint. Figure 1 shows an example in which the DNA from 15 sweet cherry cultivars in genus Prunus was

Fig. 2. A portion of AFLP polymorphism in 15 sweet cherry cultivars using leaf and fruit DNA extract and run side by side for comparison. Polymorphic bands are indicated by arrows.

crosatellite, 30 ( $71 \%$ ) had sufficient flanking sequence for primer design. The rest of the clones were discarded for not having any microsatellite or the microsatellite was too small or the microsatellite was too close to the cloning site. An intial set of 20 primer pairs were designed. After testing the efficiency of primers with the donor 'Valerij Tschkalov' sweet cherry as an internal standard and four randomly chosen sweet cherry cultivars, 15 primer pairs, which amplified very clean and easily interpretable single locus PCR product loci were chosen to analyze the selected cultivars and genotypes.

It was observed from the phage library that both $\mathrm{GA} / \mathrm{CT}$ and GT/CA repeats are abundant in the cherry genome and can be used for marker development. Our phage library resulted in an efficiency of $18 \%$ from sequencing to the production of operational loci which is almost double to that of Szewc-Mcfadden et al. (1996) who sequenced 141 clones in Brassica, in which 21 (15\%) primer pairs were designed and of these, 13 amplified polymorphism in a test array, resulting in an efficiency of $9.2 \%$ from sequencing to the production of operational loci.

We have isolated more $(\mathrm{GA} / \mathrm{CT}) \mathrm{n}$ microsatellites than $(\mathrm{GT} /$ CA)n from the phage library developed from the cherry genomic DNA. These results are in agreement with surveys in plants that amplified to display the allelic variation at microsatellite locus UCD-CH31. Four alleles were amplified by this locus in sweet cherry cultivars. This locus distingushed the four cherry cultivars, 'Van', 'Sam', 'Early Coral' and 'Burlat' from the rest of the cultivars due to their unique fingerprints. For example, the cherry cultivar Early Burlat had one homozygous putative allele at $125 \mathrm{bp}$ while the cherry cultivar Van had two putative alleles at positions 123 and $148 \mathrm{bp}$. The maximum number of cultivar specific putative alleles (allele present in only one cultivar) was observed in cultivar Brooks (3), followed by 'Sam' (2), 'Chinook' (1), 'Vista' (1), 'Larian' (1), 'Bing' (1), 'Early Coral' (1), and 'Early Burlat' (1). At all loci, no differences in SSR profiles were observed for leaf and fruit flesh DNA from the same cultivar (Fig. 1). Similarly, no differences were observed when gels were run three times separately for SSR markers. Comparison of 12 'Bing' fruit samples collected from grocery stores in the United States indicated that all samples except sample 4 have the same DNA fingerprint as that of the standard 'Bing' fruit DNA profile (Fig. 1). From the 15 primers developed in sweet cherry, $13(86.6 \%)$ generated amplification products in plum, $15(100 \%)$ in apricot and $12(80 \%)$ in peach with bands within the expected sizes.

The number of fragments produced by the AFLP protocol was highly variable, ranging from 61 to 92 with an average of 74 per lane. A total of $63(21 \%)$ polymorphic fragments were recorded in 15 sweet cherry cultivars using four primer combinations. AFLP markers generated unique fingerprints for all sweet cherry cultivars. 


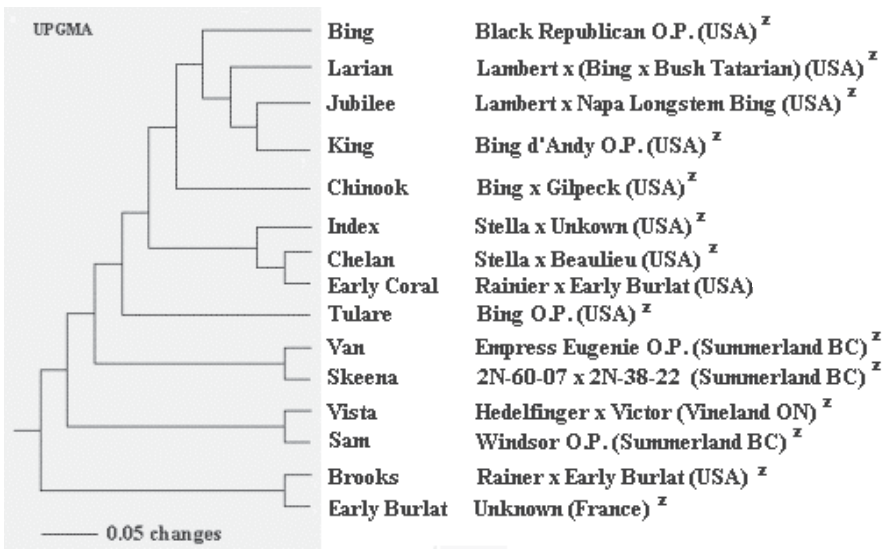

Fig. 3. Dendrogram of 15 sweet cherry cultivars constructed from the matrix based on pairwise mean character differences using SSR and AFLP markers. Parentage of each cultivar was indicated on the right for evaluation of SSR and

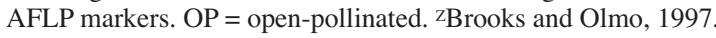

The degree and nature of polymorphism revealed by AFLP primer combination is depicted in Fig 2. A maximum number of unique bands ( band present in only one cultivar) were present in 'Tulare' (5) followed by 'Early Burlat' (4). No significant differences were observed in the AFLPfingerprints generated by four different primer combinations from both cherry leaf and fruit DNA extracts and run side by side. (Fig. 2).

Forty SSR and 63AFLPfragments from 15 sweet cherry cultivars were used to estimate the genetic distance among the cultivars and UPGMA cluster analysis shown as a dendrogram are presented in Fig 3. In this dendrogram, a close association of 'Larian', 'Jubilee', 'King', and 'Chinook' to 'Bing' could be explained due to the presence of the 'Bing' genome in the development of these cultivars as indicated by their pedigree. Pedigrees of 'Index' and 'Chelan' indicated that these two cultivars are half-sibs sharing 'Stella' as the female parent and were clustered in the same group. 'Early Coral' and 'Brooks' were believed to be originated from the same cross, but SSRs and AFLP data could not support this assumption since these are present in a different cluster. 'Tulare' is thought to have 'Bing' in its parentage, but its presence in another cluster did not support this assumption. The three British Columbian cultivars Van, Skeena, and Sam and the cultivar Vista from Vineland, Canada, are close to each other. The most divergent subcluster consisted of two cherry cultivars Brooks and Early Burlat. 'Brooks' originating from the cross ( 'Rainier' $x$ 'Early Burlat') was close to its male parent 'Early Burlat'. Most of the unique markers were observed in this cluster.

This study revealed the abundance of SSRs in the cherry genome. We have developed SSR markers with high efficiency for detecting polymorphisms and identifing cherry cultivars. The average number of SSR alleles in our study was 3.2, which was slightly higher than the 2.8 previously observed by Dirlewanger et al. (2002) in a set of 21 sweet cherry cultivars with 33 microsatellite markers. The low number of putative alleles from 1 to 5 in our study indicated in part, the narrow genetic base in this set of sweet cherry cultivars. Dirlewanger et al. (2002) found that the number of alleles observed for microsatellites in sweet cherry appeared to be relatively low (one to six) when compared with other species such as apple (one to nine).Ahigher level of polymorphism was expected in sweet cherry, given its self-incompatibility. A low degree of polymorphism in sweet cherry has been reported by Gerlach and Stosser (1998) who reported similarity indices ranging from 0.83 to 0.98 and Shimada et al. (1999) who reported similarity indices ranging from 0.51 to 0.98 by using RAPD markers. Mohanty et al. (2001) who used a RFLP-PCR technique on chloroplast DNA, achieved only a low level of resolution in a wild population of sweet cherry.

In contrast to the weak correlation between the number of alleles and the number of repeats as observed in wheat (Plaschke et al., 1995), and the stronger one in barley (Saghai Maroof et al., 1994), and peach (Raffaele et al., 2000), no correlation was detected for the 15 cherry microsatellites in our study, in concordance with the results of Szewc-Mcfadden et al. (1996) in Brassica and Valdes et al. (1993) in humans.

Our results showed amplification of more than $80 \%$ of the cherry primer pairs in plum, apricot and peach indicating a congeneric relationship within Prunus species. Therefore, a high level of sequence conservation exists within the primer sites flanking the microsatellites in the Prunus genome. A large amount of structural and functional homology between Prunus genomes has been suggested in the past. Downey and Iezzoni (2000) used SSR markers identified in other Prunus to study genetic diversity in black cherry (P. serotina Ehrh.). Sosinski et al. (2000) developed SSR markers for peach, which were partially usable in apricot and sour cherry. For use in linkage mapping, microsatellites must be informative across many species and cultivars within the genus or family. The frequencies for the transportability observed here were higher than those reported in other plants. For example, $26 \%$ of the barley (Hordeum vulgare L.) microsatellite primers amplified microsatellites from oat (Avena sativa L.) (Li et al., 2000). Lower values were even found for microsatellite loci sequenced in soybeans [Glycine $\max (\mathrm{L}$.) Merr.], from which only $10 \%$ provide useful markers for cowpeas [ Vigna unguiculata (L.) Walp.], broad beans or lupines (Lupinus albus L.) (Peakall et al., 1998). These results demonstrate that microsatellites are very powerful markers for synteny analysis in Prunus. The fact that primer pairs developed for one species can work in other species allows researchers to avoid the expensive work of developing new primers. In this sense, SSR markers appear to be promising candidates to serve as molecular markers for phylogenetic studies, where different species and even higher taxa are sampled, at least in the case of the genus Prunus.

The overall genetic diversity among the tested cherry cultivars was relatively low as evident from the polymorphic rate of $21 \%$ found by the four AFLP primer combinations in our study which is similar to the $17 \%$ reported by Boritzki et al. (2000) and to the $19 \%$ reported by Zhou et al. (2002) and the $20 \%$ reported by Struss et al. (2001). AFLP analysis reveals a higher degree of polymorphism which is necessary when studying populations with a low degree of genetic variability, such as in sweet cherry. Our data demonstrate that AFLP fingerprints can distingush cultivars of sweet cherry even in a population with limited genetic diversity. The limited genetic variability of sweet cherry revealed by our AFLP analysis is consistent with the known genetic background of cultivars.

We successfully applied two marker systems, SSRs and AFLP, for genome analysis in cherry which can be used for characterization and identification of cherry genotypes, product purity, pursuing patent protection, and ensuring the proper genetic material for cherry growers.

We also demonstrated cross species amplification of the SSR primer pairs in other Prunus species, which showed conservation of microsatellite loci among the most important Prunus species. These newly developed SSRs could be used to complete already existing Prunus maps (Dirlewanger et al., 1998; Joobeur et al., 1998) and to compare and merge in Prunus linkage maps which might speed up sweet cherry breeding programs. These markers 
can also be used for resolving trueness-to-type issues. The use of fruit for genotyping purposes is of particular interest in situations when leaves are not available for testing. We have developed methods to use fruit DNA for monitoring cultivar identity, aiding in the protection of plant breeder's rights and for quality control in the market. In conclusion, we have developed SSRs in sweet cherry and demonstrated the utility of SSRs and AFLP molecular markers for identification and characterization of sweet cherry cultivars using leaf and fruit DNA extracts.

\section{Literature Cited}

Aranzana, M.J., M.C. de Vicente, and P. Arus. 2001. Comparison of fruit and leaf DNA extracts for AFLP and SSR analysis in peach (prunus persica (L.) Batsch. Acta. Hort. 546:297-300.

Brooks, R. and H. Olmo. 1997. The Brooks and Olmo register of fruit and nut varieties. 3rd ed. ASHS Press, Alex., Va.

Boritzki, M., J. Plieske, and D. Struss. 2000. Cultivar identification in sweet cherry (Prunus avium L.) using AFLP and micro-satellite markers. Acta Hort. P538: 505-510.

Cantini, C., A.F. Iezzoni, W.F. Lamboy, M. Boritzki, and D. Struss. 2001. DNA Fingerprinting of tetraploid cherry germplasm using simple sequence repeats. J. Amer. Soc. Hort. Sci. 126:205-209.

Conditt, R. and S.P. Hubble. 1991. Abundance and DNA sequence of two-base repeat regions in tropical tree genomes. Genome 34:66-71.

Cipriani, G., G. Lot., W.G. Huang, M.T. Marrazzo, E. Peterlunger, and R. Testolin. 1999. AC/GT and AG/CT microsatellite repeats in peach (Prunus persica): Isolation, characterization and cross-species amplification in Prunus. Theor. Appl. Genet. 99:65-72.

Dirlewanger, E. and C. Bodo. 1994. Molecular genetic mapping of peach. Euphytica 77:101-103.

Dirlewanger E., V. Pronier, C. Parvery, C. Rothan, A. Guye, and R. Monet. 1998. Genetic linkage map of peach (Prunus persica $\mathrm{L}$. Batsch) using morphological and molecular markers. Theor. Appl. Genet.97: 888-895.

Dirlewanger E., P. Cosson, M. Tavaud, M.J. Aranzana, C. Poizat, A. Zanetto, P. Arus, and F. Laigret. 2002. Development of microsatellite markers in peach [Prunus persica $($ L.) Batsch] and their use in genetic diversity analysis in peach and sweet cherry. Theor. Appl. Genet. 105:127-138.

Downey, S.L. and A.F. Iezzoni. 2000. Polymorphic DNA markers in black cherry (Prunus serotina) are identified using sequences from sweet cherry, peach and sour cherry. J. Amer. Soc. Hort. Sci. 125:76-80.

Echt, C.S. and P. May-Marquardt. 1997. Survey of microsatellite DNA in pine. Genome 40:9-17.

Feinberg, A.P. and B.Vogelstein. 1983. A technique for radiolabelling DNArestriction fragments to high specific activity. Anal. Biochem. 132:6-13.

Gerlach, H.K. and R. Stosser. 1998. Sweet cherry cultivar identification using RAPD-derived DNA fingerprints. Acta Hort. 468:63-69.

Guilford, P., S. Prakash, J. M. Zhu, E. Rikkerink, S. Gardiner, H. Bassett, and R. Forster. 1997. Microsatellites in Malus $\times$ domestica (apple): abundance, polymorphism and cultivar identification. Theor. Appl. Genet. 94:249-254.

Joobeur T., M.A. Viruel, M.C. de Vicente, B. Jauregui, J. Ballester, M.T. Dettori, I. Verde, M.J. Truco, R. Messeguer, I. Batelle, R. Quarta, E. Dirlwanger, and P. Arus. 1998. Constuction of a saturated linkage map for Prunus using an almond X peach F2 progeny. Theor. Appl. Genet. 97:1034-1041.

Li, C.D., B.G. Rossnagel, and G.J. Scoles. 2000. The development of oat microsatellite markers and their use in identifying relationships among Avena species and oat cultivars. Theor. Appl. Genet. 101:1259-1268.

McCouch, R.S., X. Chen, O. Panaud, S. Temnykh, Y. Xu, Y. G. Cho, N. Huang, T. Ishii, and M. Blair. 1997. Microsatellite marker development, mapping and applications in rice genetics and breeding. Plant Mol. Biol 35:89-99.

Mohanty, A., J.P. Martin, and I. Aguinagalde. 2001. Chloroplast DNA study in wild populations and some cultivars of Prunus avium L. Theor. Appl. Genet.103:112-117

Myburg, A.A., D.L. Remington, D.M. O'Malley, R.R. Sederoff, and R.W. Whetten. 2001. High-throughput AFLP analysis using infrared dye-labeled primers and an automated DNA sequencer. Biotechniques 30:348-357.

Peakall, R., S.Gilmore, W. Keys, M. Morgante, and A. Rafalski. 1998. Cross-species amplification of soybean (Glycine max) simple-sequence-repeats (SSRs) within the genus and other legume genera. Mol. Bio. Evol.15:1275-1287.

Plaschke, J., M.W. Ganel, and M.S. Roder. 1995. Detection of genetic diversity in closely related bread wheat using microsatellite markers. Theor. Appl. Genet. 91:1001-1007.

Provan, J., W. Powell, and R. Waugh. 1996. Microsatellite analysis of relationships within cultivated potato (Solanum tubersum). Theor. Appl. Genet. 92: 1078-1084.

Raffaele, T., T. Marrazzo, G. Cipriani, R. Quarta, I. Verde, M. T. Dettori, M. Pancalli, and S. Sansavini. 2000. Microsatellite DNA in peach [Prunus persica $(\mathrm{L}$.) Batsch] and its use in fingerprinting and testing the genetic origin of cultivars. Genome 43:512-520.

Saghai Maroof, M.A., R.M. Biyashev, G.P. Yang, Q. Zang, and R.W. Allard. 1994. Extraordinarily polymorphic microsatellite DNA in barley: Species diversity, chromosomal locations, and population dynamics. Proc. Natl. Acad. Sci., USA 91:5466-5670.

Shimada, T., H. Hayama, T. Haji, M. Yamaguchi, and M. Yoshida. 1999. Genetic diversity of plums characterized by random amplified polymorphic DNA(RAPD) analysis. Euphytica 109:143-147.

Sosinski, B., M. Gannavarapu, L.D. Hager, L.E. Beck, G.J. King, C.D. Ryder, S. Rajapakse, W.V. Baird, R.E. Ballard, and A.G. Abbott. 2000. Characterization of microsatellite markers in peach [Prunus persica (L.) Batsch]. Theor. Appl. Genet. 101:421-428.

Sosinski, B., Z.X. Lu, A. Tabb, K. Sossey-Alaoui, S. Rajapakse, K. Glassmoyer, R. Scorza, G. Reighard, R.E. Ballard, W.V. Baird, and A.G. Abbott. 1998. Use of AFLP and RFLP markers to create a combined linkage map in peach [Prunus persica (L.) Batsch] for use in marker assisted selection. Acta Hort. 465:61-68.

Struss, D. and J. Plieske. 1998. The use of microsatellite markers for detection of genetic diversity in barley populations. Theor. Appl. Genet. 97:308-315.

Struss, D., M. Boritzki, K. Glozer, and S.M. Southwick. 2001. Detection of genetic diversity among populations of sweet cherry (Prunus avium L.) by AFLPs. J. Hort. Sci Biotechnol. 76:362-367.

Swofford, D.L.1999. PAUP: Phylogenetic analysis using parsimony beta test version 4.0 b2. Sinauer Assoc., Sunderland, Mass.

Szewc-McFadden, A.K., S. Kresovich, S.M. Bliek, S.E. Mitchell, and J.R. McFerson. 1996. Identification of polymorphic, conserved simple sequence repeats (SSRs) in cultivated Brassica species. Theor. Appl. Genet. 93:534-538.

Tobutt, K.R.and R. Boskovic. 1996. A cherry gene database. Acta Hort. 410: 147-153.

Tavaud, M., A. Zanetto, F. Santi, and E. Dirlewanger. 2001. Structuration of genetic diversity in cultivated and wild cherry varieties using molecular markers. Acta Hort. 546:263-269.

Valdes,A.M.,M. Slatkin, and N.B. Freimer. 1993. Allele frequencies of microsatellite loci: The stepwise mutation model revised. Genetics 133:737-749.

Vos, P., R. Hogers, M. Bleeker, M. Reijans, T. van de Lee, M. Hornes, A. Frijters, J. Pot, J. Peleman, M. Kuiper, and M. Zabeau. 1995. AFLP: A new technique for DNA fingerprinting. Nucl. Acids Res. 23:4407-4414.

Wang, Z., J.L. Weber, G. Zhong, and S.D. Tanksley. 1994. Survey of plant short tandem DNA repeats. Theor. Appl. Genet. 88:1-6.

Warburton, M.L. and F.A. Bliss.1996. Genetic diversity in peach ( Prunus persica L. batch) revealed by randomly amplified polymorphic DNA(RAPD) markers and compared to inbreeding co-efficient. J. Amer. Soc. Hort. Sci. 121:1012-1019

Zhou,L.,F.Kappel,C.Hampson,P.A.Wiersma, and G. Bakkeren. 2002. Genetic analysis and discrimination of sweet cherry cultivars and selections using amplified fragment length polymorphism fingerprints. J. Amer.Soc.Hort.Sci. 127: 786-792. 